\title{
ANALISIS WACANA KRITIS IKLAN OPERATOR SELULER
}

\author{
Anin Asnidar \\ Aninasnidar.pose@yahoo.com \\ Universitas Muhammadiyah Makassar
}

\begin{abstract}
Abstrak.
Penelitian ini adalah jenis penelitian kualitatif. Penelitian ini dilakukan dengan tujuan untuk menganalisis wacana teks iklan komersial yang direpresentasikan pada media televisi dan online. Pemaknaan kata, frasa, kalimat dalam iklan komersial dikaji dengan analisis wacana kritis Fairclough yang dilaksanakan melalui tiga tahap yaitu: deskripsi, interpretasi, dan ekspalanasi yang mengkaji tiga nilai yaitu: eksperensial, relasional, dan ekspresif dalam pilihan gramatika berupa penggunaan model kalimat. Model kalimat yang ditemukan adalah kalimat metafora pencitraan, frasa adjektiva, pewatas, kata sifat (adjektiva).

Hasil penelitian menunjukkan Bentuk kalimat yang muncul dalam wacana iklan operator seluler adalah termasuk ragam tak baku. Bahasa iklan meniru dari bahasa iklan operator selular lain, yang mengunggulkan tarif telepon murah. Pihak operator seluler berusaha menyampaikan informasi dan menarik perhatian pengguna kartu seluler. Bahasa yang disampaikan dalam iklan memiliki makna dan mencerminkan karakter dari setiap perusahaan jasa operator seluler. Semakin beragamnya operator seluler yang ada di Indonesia menimbulkan persaingan guna mendapatkan hati penggunanya. Setiap operator menggunakan kosakata yang menarik hati pelanggan seluler dan bahkan menjatuhkan operator seluler lain.
\end{abstract}

Kata kunci: iklan, seluler, wacana kritis.

\section{PENDAHULUAN}

Menemukan relasi antara dimensi ekonomi dan politik dalam kerja media tentu saja menjadi pertanyaan paling menarik. Berawal dari hal-hal yang disaksikan setiap hari melalui media; berita, iklan, film, atau berbagai tayangan hiburan. Sederhananya, apapun yang diterima dari media itulah yang dalam tulisan ini kita sebut sebagai informasi. Informasi tersusun atas serangkaian bahasa yang terstruktur menurut aturan kelaziman pemakaian, sehingga antara iklan dan berita tentu mempunyai jenis, kadar dan muatan tersendiri. Sehingga dalam kajian mengenai ekonomi politik informasi, penekanan terhadap bahasa menjadi penting. Bahkan tulisan ini mencoba menjelaskan problem ekonomi media dengan berpijak pada analisis bahasa.

Setiap wacana yang diproduksi dapat dipandang sebagai perang ideologi dan kekuasaan. Salah satu cara untuk mempertahankan dan merebut ideology yang dominan adalah melalui penguasaan dunia simbolik. Bourdieu (dalam Jufri, 2006:51) menyatakan bahwa kekuasaan simbolik adalah kekuasaan yang dapat dikenali dari tujuan untuk mendapat pengakuan. Melalui mekanisme kekerasan simbolik, kekuasaan simbolik memiliki kesempatan untuk memperluas pengaruh tanpa disadari oleh subjek. Akhirnya kelompok yang terdominasi merasa hal itu sebagai suatu kewajaran.

Di bidang ekonomi, untuk menarik perhatian dan memenuhi pandangan masyarakat, iklan menjadi media yang sangat efektif untuk pencitraan produk tertentu. Bahasa yang digunakan dilengkapi sloganslogan yang sarat dengan ideologi. Menurut Eriyanto (2002: 2) ideologi membentuk dan dibentuk oleh bahasa. Dengan ideologi orang akan memberi makna pada realitas tertentu untuk memudahkan pengolahan dan penyimpanan makna.

Iklan adalah berita pesanan untuk mendorong, membujuk kepada khalayak ramai tentang benda dan jasa yang ditawarkan; iklan dapat pula berarti pemberitahuan kepada khalayak ramai mengenai barang atau jasa yang dijual, dipasang didalam media massa seperti surat kabar dan majalah (KBBI: 322).

Iklan selalu hidup dan berada kapan saja dan di mana saja dalam kehidupan kita. Benyamin Franklin adalah orang pertama yang memperkaya informasi iklan dengan 
menambah ilustrasi sehingga efek iklan semakin kuat (Ferry Darmawan, 2005: 103114). Di Indonesia, pada masa perkembangannya, bentuk iklan bersandar pada bahasa verbal yang tertulis dan tercetak. Kekuatan utama iklan terletak pada bahasa, gambar, serta penggarapan kreatif tata letaknya. Setiap pengiklan selalu menginginkan agar produk yang dipromosikan laku. Sebab efek langsung dan cepat terhadap penjualan menjadi salah satu ukuran keberhasilan iklan. Dalam rangka memenuhi maksud tersebut, maka di dalam memproduksikan sebuah iklan, bahasa dan gambar atau ilustrasi hendaknya digarap secara cermat. Karena pada dasarnya iklan berperan penting dan sangat mempengaruhi proses pemasaran dan hasil penjualan suatu produk. Kunci kesuksesan sebuah iklan terletak pada kreativitas orang-orang yang terlibat dalam proses pembuatannya. (Siminto, 2004) Sebuah iklan diciptakan dengan memperhitungkan secara cermat aspek keberterimaan oleh masyarakat umum.

Hal-hal yang dikemukakan di atas menjadi kajian analisis wacana kritis. Analisis wacana kritis dilaksanakan melalui tiga tahap yaitu: deskripsi, interpretasi, dan ekspalanasi. Deskripsi berhubungan dengan unsur formal yang terdapat dalam teks, interpretasi berkaitan dengan teks dan interaksi sosial dengan melihat teks sebagai hasil dari proses produksi, dan eksplanasi menyangkut hubungan antara interaksi dengan hubungan sosial. Dengan demikian setiap tahap dalam analisis wacana kritis merupakan kegiatan analisis.

Informasi melalui iklan dinilai berpengaruh langsung maupun tidak langsung terhadap persepsi, pemahaman, dan tingkah laku masyarakat (Darmawan, 2006).

Analisis wacana kritis menyediakan teori dan metode yang bisa digunakan untuk melakukan kajian. Bahasa merupakan media bagi manusia dalam berkomunikasi. Melalui bahasa, manusia dapat mengungkapkan ide, pikiran, dan perasaannya. Namun demikian, saat ini definisi bahasa telah berkembang sesuai fungsinya bukan hanya sebagai alat berkomunikasi. Saat ini, bahasa telah menjadi media perantara dalam pelaksanaan kuasa melalui ideologi. Bahkan bahasa juga menyumbang proses dominasi terhadap orang lain oleh pihak lain (Fairclough, 1989:2).
Berdasarkan pandangan Fairclough, Van Dijk, dan brett Belliger tentang model wacana kritis, Jufri (2006) menemukan wacana Lontara La Galigo (LLG) bahwa wacana kritis bukan teks yang vakum dan netral, atau teks tersebut tidak murni.

Pandangan mengenai kekuasaan simbolik dalam wacana menurut Bourdieu (dalam Jufri, 2008:87) menyatakan bahwa kekuasaan simbolik adalah kekuasaan dapat dikenali dari tujuannya untuk mendapatkan pengakuan. Artinya, sebuah kekuasaan (baik ekonomi, politik, budaya, maupun status sosial) yang memiliki kemampuan untuk tidak dapat dikenali bentuk aslinya.

Penelitian ini akan membahas analisis wacana kritis bahasa iklan komersial televisi. Dalam wacana ekonomi kajian difokuskan pada bahasa iklan komersial televisi. Penelitian ini akan dikaji melalui iklan di televisi dan media.

\section{METODOLOGI}

Penelitian ini adalah penelitian kualitatif. Analisis yang digunakan dalam penelitian ini adalah Analisis Wacana Kritis (AWK) model Fairclough. Dalam penerapannya analisis wacana ini merupakan analisis terhadap tiga dimensi analisis wacana kritis, yaitu dimensi teks, dimensi wacana, dan dimensi sosiokultural.

Bahan analisisnya ialah teks wacana iklan operator seluler dari televisi dan internet. Pengumpulan data dilakukan dengan teknik analisis teks. Wacana pemberitaan dalam penelitian ini ialah kata-kata yang digunakan pihak operator seluler dalam menarik perhatian pengguna kartu telepon seluler. Operator telepon seluler masing-masing diberi kode $\mathrm{O} 1, \mathrm{O} 2, \mathrm{O} 3, \mathrm{O} 4$.

\section{HASIL PENELITIAN DAN PEMBAHASAN}

Bahasa iklan adalah ragam tulisan melalui perantara bahasa yang digunakan dalam iklan operator selular di Indonesia. Semakin memikat slogan yang digunakan dalam setiap iklan yang diterbitkan, semakin tertarik masyarakat untuk menggunakan layanan operator kartu selular dari perusahaan yang terkait.

Beragam keunggulan yang ditawarkan oleh perusahaan operator selular disampaikan melalui bahasa. 
Bahasa yang memikat dengan pilihan kata yang kreatif selalu dimanfaatkan oleh perusahaan operator selular dalam menjaring pengguna layanan kartu selular. Artinya, ada makna yang terkandung dalam setiap bahasa yang disampaikan dalam slogan operator selular tersebut sehingga setiap pilihan kata yang dipakai oleh perusahaan penyedia jasa operator selular, memiliki makna yang ingin disampaikan dan mencerminkan karakter dari setiap perusahaan jasa operator selular. Oleh sebab itu, dengan semakin beragamnya operator seluler yang ada di Indonesia menimbulkan persaingan guna mendapatkan hati penggunanya.

Perseteruan operator seluler paling seru saat ini adalah antara O1 dan O2. Kita dapat melihat iklan-iklan $\mathrm{O} 1$ dan $\mathrm{O} 2$ saling menjatuhkan dengan cara saling memurahkan sendiri. Persaingan kartu yang sudah ternama ini kian meruncing dan langsung tak tanggung-tanggung menyindir satu sama lain secara vulgar. Kedua operator ini secara bersamaan menggunakan Jargon "Telefon Murah."

Pemaknaan kata, frasa, kalimat dalam iklan komersil dikaji dengan teknik analisis Fairclough mencakup kajian terhadap tiga nilai eksperensial, relasional, dan ekspresif dalam pilihan gramatika berupa penggunaan model kalimat. Model kalimat yang ditemukan adalah kalimat metafora pencitraan, frasa adjektiva, pewatas, kata adjektiva.

\section{Data 1}

Operator O1 membuat promosi iklan yang menarik bagi pengguna dengan membuat episode cerita keluarga ASikin dengan berbagai tema menarik yang berkaitan dengan kehidupan sehari-hari. Iklan keluarga ASikin episode "Paket Mingguan Bikin Kenyang." Pada data 1 kartu O1 versi Gulai Otak adalah iklan yang mengiklankan "Paket Kenyang Internetan" dari Kartu O1. Secara eksperensial Paket Kenyang Internetan termasuk metafora pencitraan karena pihak operator menggunakan bahasa figuratif untuk menyampaikan informasi. Maksud dari "Paket kenyang internetan" adalah paket internet murah dan memuaskan pengguna kartu seluruh masyarakat Indonesia. Harganya lebih murah dan mampu dijangkau oleh siapapun serta memberikan kepuasan pada pengguna. Mulai remaja, hingga orang tua, bahkan dari segala suku apapun bisa menggunakan "Paket
Kenyang Internetan". Hal ini terlihat dari keragaman karakteristik yang dimiliki oleh anggota Keluarga Asikin sebagai pelaku dalam setiap episode iklan.

Berdasarkan data di atas, kalimat "Paket Kenyang Internetan" digunakan oleh operator untuk menawarkan kebebasan dan kepuasan untuk semua pengguna kartu O1 dalam memilih paket yang diinginkan dengan harga mulai dari Rp 5000,-. Hal itu sejalan dengan pendapat Larson (1998: 271-271) yang menekankan bahwa, metafora merupakan ungkapan figuratif yang didasarkan pada perbandingan.

\section{Data 2}

Operator O1 menyindir Operator O2, hal itu terlihat dari kata-kata bintang iklan Operator O1. "Tenang...tenang, pokoknya saya sudah tobat, hanya kartu Ol yang paling murah langsung dari menit pertama gak ribet, gak ada batas-batasnya, pagi..siang..malam. Pokoknya saya kapok dibohongi anak kecil". Maksud frasa paling murah adalah kartu $\mathrm{O} 1$ memiliki kelebihan jika dibandingkan dengan kartu lain, tidak perlu menunggu 2 menit untuk dapat paket murah seperti yang berlaku pada kartu lain, tidak perlu lama cek-cek kuota, dan tidak ada batas waktu pemakaian mulai pagi sampai malam, tidak seperti operator lain yang harus cek kuota terlebih dahulu, dan memiliki batas waktu pemakaian. Operator ingin menarik perhatian pengguna dengan menggunakan frasa paling murah, tidak ribet, tidak ada batas waktu pemakaian.

Secara gramatika paling murah termasuk frasa adjektiva, karena kata paling murah terdiri dari dua kata dan tidak melampaui batas fungsi. Hal ini sejalan dengan pendapat Ramlan tentang frasa, yaitu satuan gramatikal yang terdiri dari dua kata atau lebih yang tidak melampaui suatu batas fungsi yang terdapat dalam klausa.

\section{Data 3}

Iklan O2 "Berkah untuk berbagi."Beli smartphone baru dengan kartu perdana, dapat youtube tanpa kuota 1 tahun. Pada iklan tersebut sangat jelas kalau $\mathrm{O} 2$ menyindir O3. Dalam iklan tampak sebuah toko HP (nuansa toko warna kuning termasuk baju karyawan, sama dengan warna kartu O3) tutup karena pelanggan beralih ke toko $\mathrm{O} 2$ yang menawarkan paket murah.

"Berkah untuk berbagi." Beli smartphone baru dengan kartu perdana, dapat 
youtube tanpa kuota 1 tahun. Kalimat berkah untuk berbagi digunakan untuk menarik perhatian pengguna kartu perdana O2, pengguna mendapat berbagai keuntungan berupa 1 tahun youtube tanpa kuota, nelpon sepuasnya dengan WhatsApp dan Line (voice dan video call), serta nonton film Indonesia lewat berlangganan gratis aplikasi terbaru $\mathrm{O} 2$ super nonton. Pengguna tidak akan rugi membeli kartu perdana pada kartu O2. Kalimat "Berkah untuk berbagi" secara eksperensial termasuk metafora, sebab dalam kalimat berkah untuk berbagi pihak operator $\mathrm{O} 2$ bermaksud untuk memberikan gambaran informasi dengan menggunakan bahasa figuratif pada pengguna, bahwa kartu $\mathrm{O} 2$ memberikan berbagai keuntungan bagi pengguna kartu perdana. Dengan menggunakan kartu $\mathrm{O} 2$ pengguna akan mendapatkan keberkahan dan keuntungan. Hal itu sejalan dengan pendapat Larson (1998: 271271) yang menekankan bahwa, metafora merupakan ungkapan figuratif yang didasarkan pada perbandingan.

\section{Data 4}

Iklan $\mathrm{O} 2$ versi lain "Murahnya beneran RP 25 dari menit pertama". Di iklan tersebut, Baim diberitahu Putri Titian untuk komentar, "Om sule ganteng", tapi dengan kepolosan dan kejujuran (yang tentu saja sudah direkayasa oleh sutradara) Baim ngomong, "Om Sule jelek". Sule kemudian membujuk Baim dan memberikan dua buah makanan kepada Baim dengan harapan Baim akan mengatakan ' $\mathrm{Om}$ Sule ganteng'. Namun Baim masih menjawab apa ada seperti jawaban sebelumnya. "Dari pertama, Om Sule itu jelek". "Dari pertama kalau Rp. 25,- kartu O2, beneran murahnya" Jawab Baim lagi.

"Dari pertama kalau Rp. 25,- kartu O2, beneran murahnya, melalui kalimat tersebut, operator ingin menyampaikan pada pengguna, bahwa kartu $\mathrm{O} 2$ benar-benar murah mulai menit pertama. Iklan yang disampaikan benar-benar sesuai kenyataan, bukan sekadar untuk menarik perhatian pengguna kartu $\mathrm{O} 2$.

Kata beneran adalah bentuk tidak baku dari kata benar. Kata benar memiliki arti sesuai sebagaimana adanya, betul, tidak salah. Dalam bahasa Indonesia masuk dalam pertarafan adjektiva. Adjektiva bertaraf dapat menunjukkan berbagai tingkat kualitas atau intensitas dan berbagai tingkat bandingan yang dinyatakan dengan pewatas. Murahnya adalah kata adjektiva yang mendapatkan klitik -nya. Klitik varian pronomina persona $\mathrm{ia} /$ dia dan pronomina benda yang menyatakan milik, pelaku atau penerima. Hal tersebut sejalan dengan pendapat Alwi (2003:171) secara tradisional, adjektiva dikenal sebagai kata yang mengungkapkan kualitas atau keadaan suatu benda. Adjektiva adalah kata yang memberikan keterangan yang lebih khusus tentang sesuatu yang dinyatakan dalam kalimat.

\section{Data 5.}

Iklan operator O4 "Jagoan super yang sesungguhnya, apapun terkuras dengan kharismanya, inilah 2 jagoan super yang sesungguhnya, kalau kamu pingin si super, Cak Noris pakai si super. Hemat Cuma Rp 5000, bisa buat nelfon SMS, internet seharian sepuasnya, super baik kan.

Berdasarkan data di atas melalui kata super, operator $\mathrm{O} 4$ ingin menyampaikan informasi dan menarik perhatian pengguna, bahwa kartu $\mathrm{O} 4$ memiliki kelebihan atau keistimewaan dari kartu lain, semua kelebihan dimiliki oleh kartu O4. Jadi, kalau ingin mendapatkan hemat nelfon, SMS, internet seharian tanpa batas waktu gunakan kartu O4. Operator menggunakan super sebagai power untuk menarik perhatian pengguna.

Secara gramatika, kata super termasuk adjektiva. Super berarti lebih dari yang lain, luar biasa, istimewa (KBBI V).

Adjektiva dikenal sebagai kata yang mengungkapkan kualitas atau keadaan suatu benda. Kata yang memberikan keterangan yang lebih khusus tentang sesuatu yang dinyatakan dalam kalimat. (Alwi, 2003:171)

\section{Data 6}

Pilih paket maksimal, kualitas terbaik, tanpa resiko. Telpon dan SMS sepuasnya. Menghubungkan jutaan orang, menyatukan jutaan hati.

Melalui kalimat di atas Operator iklan ingin menarik perhatian pengguna dan menyampaikan informasi bahwa kartu $\mathrm{O} 1$ memiliki kualitas terbaik dibanding operator lain, tanpa ada resiko, bisa menelpon dan SMS sepuasnya sehingga mampu menghubungkan jutaan orang.

Berdasarkan data di atas, arti kalimat Menghubungkan jutaan orang, menyatukan jutaan hati adalah kartu O1 bisa digunakan untuk menelpon dan SMS sepuasnya, tanpa 
takut kehabisan pulsa. Secara eksperensial, kalimat menghubungkan jutaan orang, menyatukan jutaan hati termasuk metafora pencitraan, karena operator menggunakan bahasa figuratif, ungkapan untuk menarik perhatian pengguna agar menggunakan kartu O1. Hal tersebut sejalan dengan pendapat (Classe: 2000: 941) tentang metafora yaitu penggunaan citra, makna, atau kualitas sebuah ungkapan kepada suatu ungkapan lain. Pengalihan tersebut dilakukan dengan cara merujuk suatu konsep kepada suatu konsep lain untuk mengisyaratkan kesamaan, analogi atau hubungan kedua konsep.

\section{Data 7}

"Perubahan telah datang, untuk dunia digital yang lebih baik, nikmati semua yang kamu suka, lebih cepat dan tetap lebih cepat di mana saja"

"Dengan jaringan data kuat di Indonesia, bisa terhubung dengan jutaan teman di mana saja, dan tanpa biaya tambahan, 4GP untuk semua."

Pada kalimat di atas operator ingin menyampaikan bahwa kartu O3 mempunyai terobosan baru, dengan jaringan data lebih kuat dan lebih cepat, bisa terhubung dengan banyak orang kapan saja dan dimana saja tanpa biaya tambahan. Makna lebih cepat dalam teks adalah lebih cepat terhubung dalam waktu singkat dapat terhubung dengan siapa pun dan kapan pun dengan biaya murah. Operator menggunakan kata lebih cepat untuk mendapatkan respon dari pengguna kartu, sehingga tertarik menggunakan kartu O3. Lebih cepat termasuk frasa adjektiva, karena lebih cepat terdiri dari dua kata dan tidak melampaui batas fungsi. Hal ini sejalan dengan pendapat Ramlan tentang frasa, yaitu satuan gramatikal yang terdiri dari dua kata atau lebih yang tidak melampaui suatu batas fungsi yang terdapat dalam klausa.

\section{PENUTUP}

Bentuk kata serta unsur gramatikal yang muncul dalam wacana iklan operator seluler adalah termasuk ragam tak baku. Pilihan kata yang dipakai oleh perusahaan penyedia jasa operator seluler, memiliki makna yang ingin disampaikan dan mencerminkan karakter dari setiap perusahaan jasa operator selular. Oleh sebab itu, dengan semakin beragamnya operator seluler yang ada di Indonesia menimbulkan persaingan guna mendapatkan hati penggunanya. Berdasarkan hasil penelitian, model kalimat yang ditemukan dari analisis teks adalah kalimat metafora, metafora pencitraan, frasa adjektiva, pewatas.

Iklan sudah menjadi bagian hidup. Hal itu sudah tidak dapat dipungkiri. Iklan pun telah memberikan penghidupan bagi berbagai sektor, baik secara langsung maupun tidak. Mulai dari jasa advertising, percetakan, media, aktor/aktris yang menjadi bintang iklan dan masih banyak bidang lain yang mengeruk keuntungan. Iklan dibuat dan ditayangkan tidak untuk merusak, hal itu adalah proses kreatif. Iklan sebagai proses kreatif dalam berkomunikasi dengan masyarakat. Namun, cara berkomunikasi tersebut kerap dan bisa saja diterima atau dipersepsikan berbeda-beda oleh berbagai pihak.

\section{DAFTAR PUSTAKA}

Cutting, Joan. 2002. Pragmatics and Discourse. London \& New York: Routledge. Classe, Oliver (Ed.). Encyclopedia of Literary Translation into English. (Vol. 2). (London: Fitzroy Dearborn Publishers, 2000).

Ba'dulu, Abdul Muis. 2010. Discourse Analysis. Makassar:UNM.

Eriyanto. 2002. Analisis Wacana: Pengantar Analisis Teks Media. Yogyakarta: LKIS.

Fairclough, Norman. 2003. Language and Power. Malang: Boyan Publishing.

Fashri, Fauzi. 2014. Pierre Bourdieu: Menyingkap Kuasa Simbol. Yogyakarta:Jalasutra,

Jufri \& Achmad Tolla. 2017. Wacana Kritis. Makassar: Universitas Negeri Makassar

Jufri \& Achmad Tolla. 2012. Pertarungan Simbolik dalam Wacana. Makassar: Program Pascasarjana UNM

Jufri. 2008. Analisis Wacana Kritis. Makassar: Universitas Negeri Makassar.

Ritzer, George.2014. Teori Sosiologi Modern. Edisi Ketujuh. Terj. Triwibowo BS, Jakarta: Kencana.

Siminto. 2004. "Analisis Wacana Iklan Televisi Royko Rasa Terasi" dalam Sumarlan, Agnes Adhani dan Indratmo. Bandung: Pakar Raya. 
Tim Redaksi KBBI Pusat Bahasa. 2011. Kamus Besar Bahasa Indonesia, Pusat Bahasa, Edisi Keempat. Jakarta: Gramedia Pustaka Utama.
Van Dijk, Teun A. 1985. Handbook of Discourse Analysis (volume 1). London: Academic Press. 